\title{
Recent Changes in Reserve Requirements: An Example of Contradictory Regulation
}

\author{
R. ALTON GILBERT
}

0 NE responsibility of the Federal Reserve System is to promote sound banking practices. In recent years this Federal bank regulator has been concerned that some banks were tending to leave themselves vulnerable to liquidity crises by concentrating a large share of their time deposits in short maturities, particularly large certificates of deposit ${ }^{1}$. One tool that the Board has used to counter this tendency has been higher reserve requirements on short-term time deposits than on longer maturity deposits. The latest such Board action came in October 1975 and January 1976 when reserve requirements were reduced on member bank time deposits with naturities of 180 days or more ${ }^{2}$.

In the aggregate, banks are likely to respond to these policy actions by reducing the percentnge of time deposits held in maturities of less than 180 days. However, since these policy actions are intended primarily to reduce the vulnerability of banks to liquidity crises, their success should be judged not only in terms of aggregate maturity shifts, but also in terms of effects on the maturity structure of individual banks. As indicated in the following analysis, these reductions in reserve requirements are likely to have effects on some individual member banks which are

The assumption that a bank is more vulnerable to liquidity crises when its time deposits are concentrated in short maturities can be illustrated in the following example. Assume that a bank experiences a temporarily large decline in the value of its assets, for whatever reason. If its time deposits are concentrated in short-term maturities, the bank may be forced to liquidate some of its less liquid assets in order to meet its current obligations, since it is mnlikely that the bank could attract additional deposits during the adjustment period. The asset liquidation further reduces the bank's net worth, which aggravates its financial position and extends the period of adjustment, thereby allowing time for more short-term time deposits to reach maturity - a vicious eircle which could result in a bank fatlerre.

2Federal Reserve Bulletin (October 1975), p. 705, and (January 1976), p. 66. opposite to those intended. It appears that only a small portion of member banks in the Eighth District are affected by these recent policy actions, and some of the banks that are affected actually have incentives to shorten the maturity structure of their time deposits.

\section{PECENT CHANGES MN PESERVE REQUIREMENTS}

Before the fall of 1974 the maturity structure of bank time deposits was not influenced by differential reserve requirements. The maturity structure of time deposits depended upon the maturity structure of bank assets, interest rates on time deposits of various maturities, interest rate expectations, and interest ceilings on deposits.

In September 1974 the Board removed marginal reserve requirements on large certificates of deposit (CDs) with initial maturities of 4 months or more, leaving a marginal reserve requirement of 3 percent on large CDs with initial maturities of less than 4 months. $^{3}$ This action created a differential in reserve requirements which favored longer-term time deposits. In December 1974 all marginal reserve requirements on large CDs were removed and reserve requirements on $30-179$ day time deposits over $\$ 5$ million were raised to 6 percent, with reserve

\footnotetext{
3 Marginal reserve requirements on CDs of $\$ 100,000$ and over were imposed in June 1973. An extra (marginal) reserve requirement of 3 percent (in addition to the 5 percent reserve requirement on time deposits in effect at that time) applied to the amount of a bank's large CDs above the average amount it had outstanding in the week ending May 16,1973 . The marginal reserve requirements in effect until December 1974 continued to apply to large CDs over the average amount held in the week ending May 16, 1973, but did not apply to banks with aggregate obligations less than $\$ 10$ million. For more details, see the Federal Heserve Bulletin (November 1974), p. 800 .
} 


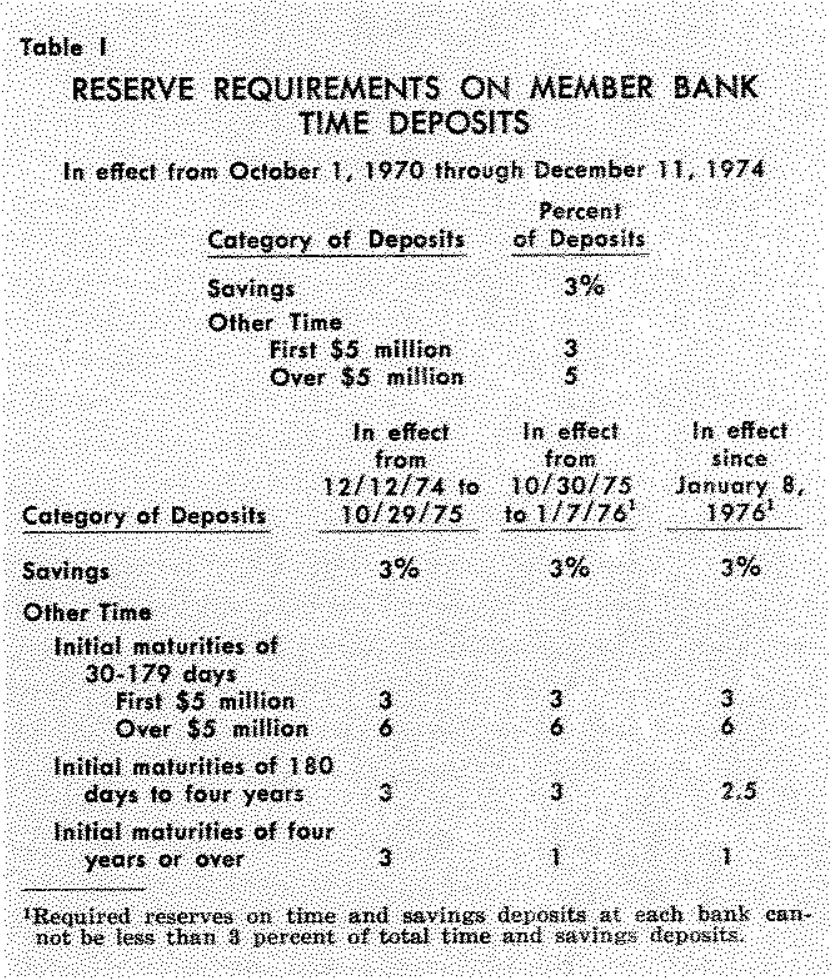

requirements on all other time deposits set at 3 percent (see Table I). The intended effect of this policy action was to induce banks to shift into obligations of more than 179 days. This effect was realized as the percentage of time deposits in maturities of 30-179 days declined steadily from December 1974 to September 1975 .

The reserve requirement changes in October 1975 and January 1976 were designed to give banks even greater incentives to lengthen the maturity siructures of their time deposits. Reserve requirements on time deposits with initial maturities of 4 years and over were reduced from 3 percent to 1 percent in October 1975 , and in January 1976 reserve requirements on time deposits with maturities of 180 days to 4 years were reduced from 3 percent to 2.5 percent. Federal Reserve regulations, however, state that a member bank's required reserves on total time and savings deposits can be no less than 3 percent of its total time and savings deposits. In other words, a member bank's required reserves on time deposits must equal the amount based upon applying the relevant percentages to each category of time deposits or 3 percent of total time deposits, whichever is larger. The 3 percent minimum is crucial for the following analysis.

The two recent changes in reserve requirements on time deposits (October 1975 and January 1976) are analyzed in this note as one policy action in order to consider their combined effects. The response of an individual bank will depend on the maturity structure of its time deposits at the time of the reserve requirement change. Table II illustrates this situation by dividing Eighth District banks into three groups according to their time deposit maturity structure.

Member banks with less than $\$ 5$ million in $30-179$ day time deposits have no incentive (from a reserve requirement standpoint) to change their maturity structure. ${ }^{4}$ For these banks, reserve requirements on each maturity group of time deposits were set at 3 percent in December 1974 and are still effectively 3 percent on each maturity group because of the 3 percent minimum rule.

A second group of member banks has an incentive to lengthen the maturity structure of time deposits. Under the new reserve requirements, their required reserves on total time deposits are greater than 3 percent because they have a relatively large propor * tion of their time deposits in 30-179 day maturities. These banks can decrease their total required reserves by shifting a larger share of their time deposits to longer maturities. The amount by which a bank in this group can reduce its required reserves is still limited by the 3 percent minimum rule. ${ }^{*}$

A third group of member banks, on the other hand, has an incentive to shift some time deposits to shorter maturities, the opposite response to that which was intended. Each of these banks had over $\$ 5$ million in 30-179 day time deposits, but their total reserve requirements on time deposits was the minimum 3 percent because they had a relatively large amount of time deposits in longer maturities."

* Except to the extent that they are discouraged from expanding deposits of $30-179$ day maturities beyond $\$ 5$ million.

The condition requited for a member bank's average reserve requirement on time deposits to be above 3 percent under the new reserve requirements is given as follows:

Let $\mathrm{S}$ be a bank's $30-179$ day deposits

M be a bank's 180 day - 4 year deposits $\mathrm{L}$ be a bank's deposits with maturities of 4 years
and over

(.03) \$5 million $+(.06)(S-\$ 5$ million $)+$

$(.025) \mathrm{M}+(.01) \mathrm{L}>(.03)(\mathrm{S}+\mathrm{L}+\mathrm{M})$

The eondition is equivalent to

(.03) $(\mathrm{S}-\$ 5$ million $)>(.02) \mathrm{L}+(.005) \mathrm{M}$

If, by lengthening the maturities of time degosits, these inequalities become equalities, a bank's average reserve requirement on its time deposits becomes the minimum 3 percent.

${ }^{6}$ Using the notation in footnote 5 , the conditions required for banks to be in this third group are as follows:

$$
\begin{gathered}
S-\$ 5 \text { million }>0 \text { and } \\
(.02) L+(.055) M \geq .03(S-\$ 5 \text { million })
\end{gathered}
$$


Table II

CHARACTERISTICS OF EIGHTH DISTRICT MEMBER BANKS WITH DIFFERENT IACENTIVES TO CHANGE THE MATURITIES OF THEIR TIME DEPOSITS

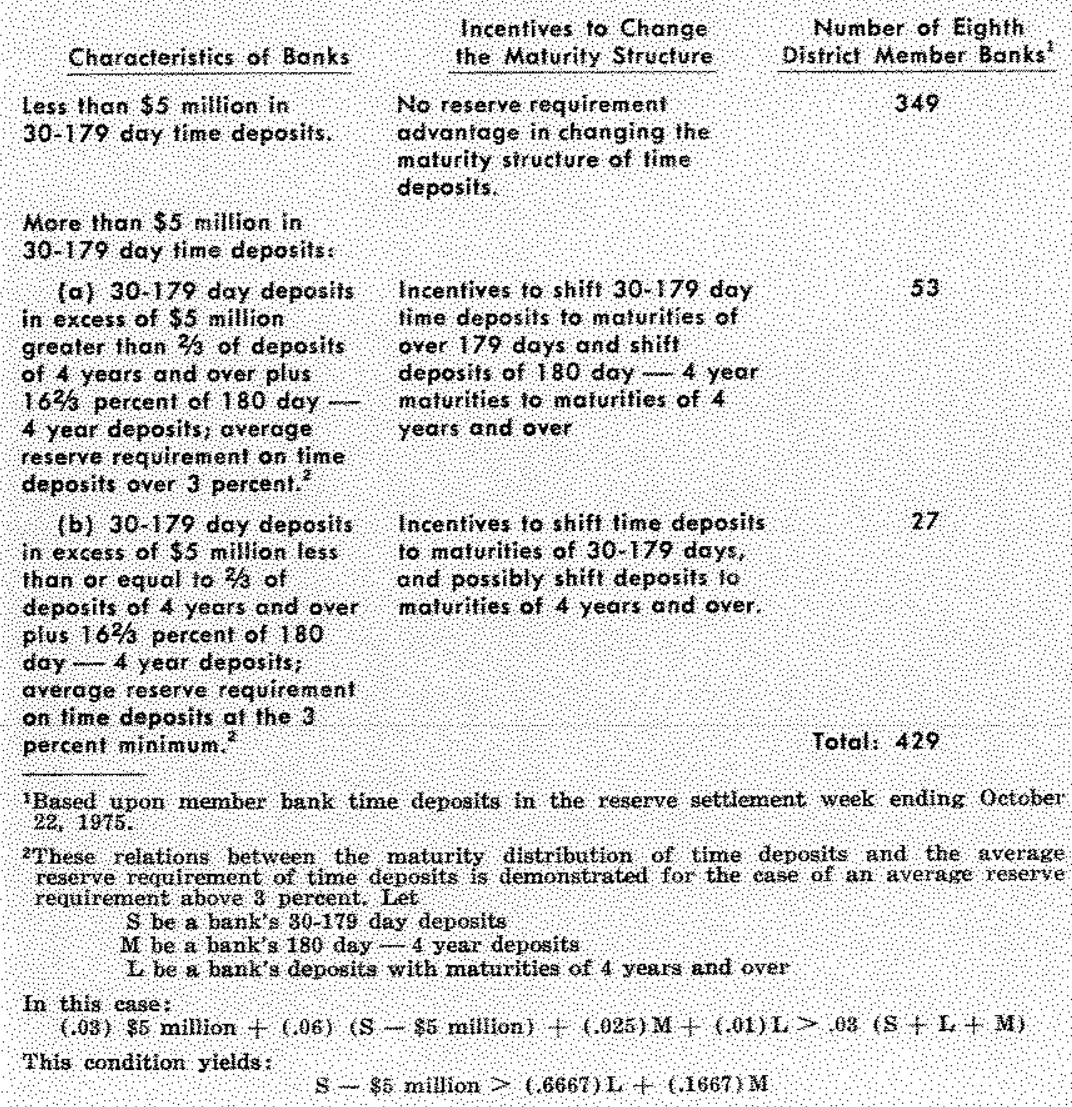

When the recent changes in reserve requirements went into effect, the proportions of time deposits these banks had in short maturities are assumed to be smaller than if reserve requirements had been uniform on all maturities of time deposits. Under the new reserve requirements, banks in the third group can shift some deposits with maturities of over 179 days to maturities of 30-179 days without increasing their total required reserves because of the 3 percent minimum rule. Therefore, for these banks the penalty on short-term time deposits imposed in December 1974 is effectively removed. ${ }^{7}$ However, all of these statements about tendencies for banks to alter the maturity structure of their time deposits must be qualified to the extent that interest cellings on time deposits prevent banks from inducing their customers to change maturities of deposits.

\footnotetext{
TSome banks in this third group may also increase the proportion of their time deposits with maturities of 4 years and over in response to the recent changes in reserve requirements. Suppose banks in this third group increase their time deposits in short maturities to the levels they would desire in the absence of differential reserve requirements by shifting
}

\section{INCENTIVES FOR ALTEING MATURTT STIUTCOUR: EIGHTH DISTRICT MEMRER BANKS}

Time deposits at member banks in the Eighth District are examined to determine their incentives for changing the maturity structure of their time deposits under the new reserve requirements. The deposits are for the week ending October 22, 1975 - the first week for which the reserve requirement change of October 1975 applies. ${ }^{8}$ Current reserve requirements are applied to those deposits to determine whether reserve requirements on time deposits would have been above or equal to 3 percent of total time deposits. ${ }^{\theta}$

Of the 429 member banks in the Eighth District, only 80 are affected by the recent reserve requirement changes (those with more than $\$ 5$ million in 30 179 day time deposits). The relevant total reserve requirement on time deposits was the minimum 3 percent for 27 of those 80 banks and above 3 percent

deposits out of 180 day - 4 year maturity dem posits. The average reserve requirements on time deposits would be above 3 percent for some of these banks; they cotald keep their average reserve requirements on time deposits at the minimum 3 percent by also shifting deposits out of 180 day -4 year deposits to maturities of 4 years and over.

8 Under lagged reserve requirements in effect since September 1968, required reserves of a member bank for each settlement week (ending each Wednesday) are based upon its deposit liabilities two weeks earlier. The deposit liablities of a member bank in the week ending October 22,1975 determined its required reserves for the settlement week of October 30 through November $5,1975$.

An alternative approach would involve analyzing the implica tions of each change in reserve requirements using deposit data for the first weeks to which each change in reserve requirements apply. This approach would create problems for determining the effects of the combined changes in reserve requirements on the incentives for banks to change the maturity structure of their time deposits. Suppose, for example, that by January 1976 banks had made partial adjustments in the maturity structures of their time deposits in response to the reserve requirement change in October 1975. In this situation there would be ambiguity as to the number of banks that would have incentives to shift deposits to short maturities under the combined changes in reserve requirements and the amount by which they could shift deposits to short maturities without increasing their required reserves. Some banks would have incentives to lengthen the maturity structure of their time deposits under the October 1975 change and shorten maturities under the change in January 1976. These oftsetting infuences can be netted out by applying the two changes to time deposit balances in the week ending October 22, 1975. 


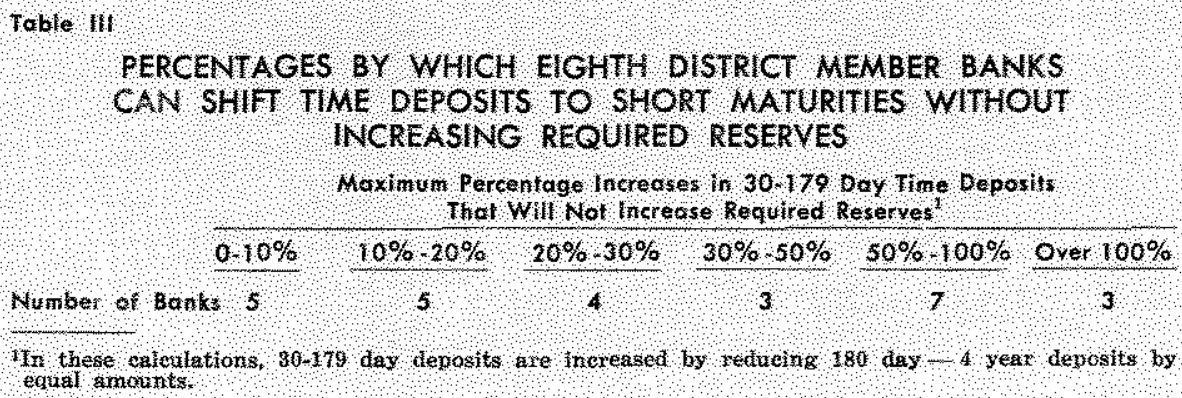

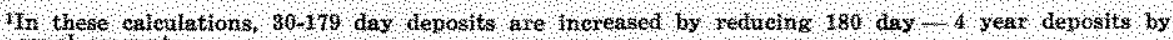
equal amoines:

for the other 53 banks. Therefore, only 53 member banks in the Eighth District have incentives to lengthen the maturity structure of their time deposits, while 27 actually have incentives to shift deposits to maturities of $30-179$ days. ${ }^{10}$

Total deposits of banks that have incentives to shift time deposits to short maturities range from about $\$ 18$ million to $\$ 130$ million. Table III gives information on the extent to which these banks can shift deposits to short maturities without increasing their required reserves. Note that 10 banks can increase their short-term deposits by more than 50 percent, and of these 10,3 can more than double their short-term deposits without increasing their total required reserves. These 27 banks can increase their $30-179$ day time deposits by a total of $\$ 76.7$ million without increasing their required reserves. ${ }^{n}$

Several of the 53 banks in the Eighth District with average reserve requirements on their time deposits above 3 percent have limited incentives to lengthen the maturity structure of their time deposits because of the 3 percent minimum rule. Suppose these banks

10Limiting the analysis to only those banks with over $\$ 5$ million in 30-179 day deposits may understate the number of banks with incentives to increase their short-term deposits under the new reserve requirements. Suppose that in October 1975 some banks would have preferred to have more than $\$ 5$ million in $30-179$ day deposits if there had been no penalty on those deposits, but they reduced their $30-179$ day deposits to below $\$ 5$ million in response to the penalty. Those banks could shift some of their longer-tem deposits to short maturities, bringing their $30-179$ day deposits to over $\$ 5$ million, without increasing their required reserves. If there were stich banks, they would have tended to keep their $30-179$ day deposits just below $\$ 5$ million before the recent changes in reserve requirements. In the week ending October $22,1975,6$ member banks in the Eighth District had between $\$ 4.75$ and $\$ 5$ million in $30-179$ day deposits, and 3 of those banks had between $\$ 4.9$ and $\$ 5$ million. Some of these banks may have incentives to increase their short-term deposits under the new reserve requirements.

11The reserve requirenent reduction in January 1976 increased the number of banks with incentives to shift deposits to short maturities above the number given such incentives by the policy action in October 1975 alone. With only the first reduction in reserve requirements (reserve requirements on deposits with maturities of 4 years or more reduced from minimum with less than 5 percent reductions in the 30-179 day deposits.

In the aggregate, however, the percentage of time deposits in 30 179 day maturities at Eighth District member banks is likely to decline. Banks with incentives to reduce their short-term deposits are generally larger than the banks with incentives to increase. As one possible response, suppose that the 53 banks in the District with average reserve requirements on time deposits over 3 percent reduce their $30-179$ day deposits by 10 percent or until the 3 percent minimum rule is reached, whichever comes first. In addition, the 27 banks with incentives to shift deposits to short maturities do so by the maximum amount without increasing their required reserves. These reactions would generate a net decrease of $\$ 117.9$ million in $30-179$ day deposits. Also note that banks with incentives to lengthen the maturity of their time deposits will tend to complete their adjustment to the recent changes in reserve requirements faster than banks with incentives to shorten, since short-term deposits can be converted to long-term deposits faster than long-term deposits can be converted to short-term.

\section{SUMHARY}

In October 1975 and January 1976 the Federal Reserve Board lowered reserve requirements on time deposits with maturities of over 179 days to induce nember banks to lengthen the maturity structure of their time deposits. The effectiveness of these policy actions is limited by a constraint on the reduction in reserve requirements: a member bank's required

3 percent to 1 percent), 16 banks in the Eighth District had incentives to shift deposits to short maturities. With the second change (reserve requirements on 180 day 4 year deposits lowered from 3 percent to 2.5 percent), 11 more banks were given such incentives. Those first 16 banks could shift a total of $\$ 46$ million in 180 day -4 year deposits to maturities of $30-179$ days without increasing their required reserves under the first change, and conld shift $\$ 62.8$ milion to $30-179$ day maturities without increasing their required reserves when the second change is added. 
reserves on time deposits can be no less than 3 percent of its total time deposits. Banks with less than $\$ 5$ million in 30-179 day time deposits are not affected by these changes in reserve requirements; most member banks are in this category. Among the larger member banks, some have incentives to lengthen the maturity structure of their time deposits under the new reserve requirements, and others are given incentives to shorten. In the Eighth Federal Reserve District, only about one-fifth of the member banks are affected by these recent policy actions, and about one-third of the larger banks which are affected have incentives to shorten the maturity structure of their time deposits.

\section{APPENDIX}

Table A-I illustrates conditions under which a bank would shorten the maturity structure of its time deposits in response to the recent change in reserve requirements. A hypothetical member bank has $\$ 100$ million in time and savings deposits throughout the discussion." The behavior of the bank is analyzed as though both of the recent changes in reserve requirements went into effect at the same time. This approach avoids analyzing effects of the reserve requirement changes separately. In December 1974 the bank had $\$ 25$ million in 30-179 day time deposits, but by the time the recent changes in reserve requirements were imposed, it had reduced its 30.179 day time deposits to $\$ 15$ million because of the 6 percent reserve requirement, while increasing time deposits with maturities between 180 days and 4 years by $\$ 10$ million. Applying the new reserve requirements to each category of time and savings deposits would indicate required reserves of only $\$ 2.775$ million, which

\footnotetext{
This discussion abstracts from the effects that changes in reserve requirements have on total deposits. To illustrate such an effect, with the time and savings deposits held by the hypothetical bank in Table A-I as of October 1975 , the bank's required reserves on time and savings deposits declined from $\$ 3.3$ million to $\$ 3$ million when reserve requirements were changed. The bank could have expanded its deposits with the reserves that were freed by the reduction in reserve requirements. In the illustration in Table A-I total time and savings deposits are held constant and reserves changed because the issue investigated in this note is the effect of changes in reserve requirements on the maturity distribution of time deposits and not effects on excess reserves and deposit expansion. Effects on the maturity distribution of time deposits are probably easier to understand if total deposits are held constant and their maturity distribution changed than if reserves were held constant, and total deposits and their maturity distribution changed.
}

would be only 2.775 percent of total time and savings deposits [see column (3)]. However, because of the 3 percent minimum rule, the bank's actual required reserves on time and savings deposits would be $\$ 3$ million.

The responses of banks to the recent reserve requirement changes depend upon such influences as the maturity preferences of banks for deposits and the changing pattern of interest rates on time deposits of various maturities. Therefore, the actual response of a bank with a maturity distribution of deposits like that of the hypothetical bank in Table A-I is uncertain. Nevertheless, such banks have incentives to shift some of their deposits to short maturities, and the two possible responses illustrated in columns (4) and (6) of Table A-I indicate the types of adjustments such banks are likely to make in the maturity distribution of their time deposits.

In the first possible adjustment, the bank shifts $\$ 6.45$ million of its 180 day -4 year deposits to maturities of 30-179 days. This is the maximum such change in maturities the bank can make without increasing its required reserves [see column (5) of Table A-I].

Note that in this first adjustment the hypothetical bank has still not restored its short-term time deposits to the level desired before the penalty was imposed on those deposits ( $\$ 25$ million in 30-179 day deposits). As illustrated in columns (6) and (7) of Table A-I, the bank can restore its short-term deposits to that desired level without increasing its required reserves if it also shifts $\$ 8.33$ million from 180 day - 4 year deposits to deposits with maturities of 4 years and over. With short-term deposits of $\$ 25$ million and long-term deposits of $\$ 18.33$ million, required reserves would 


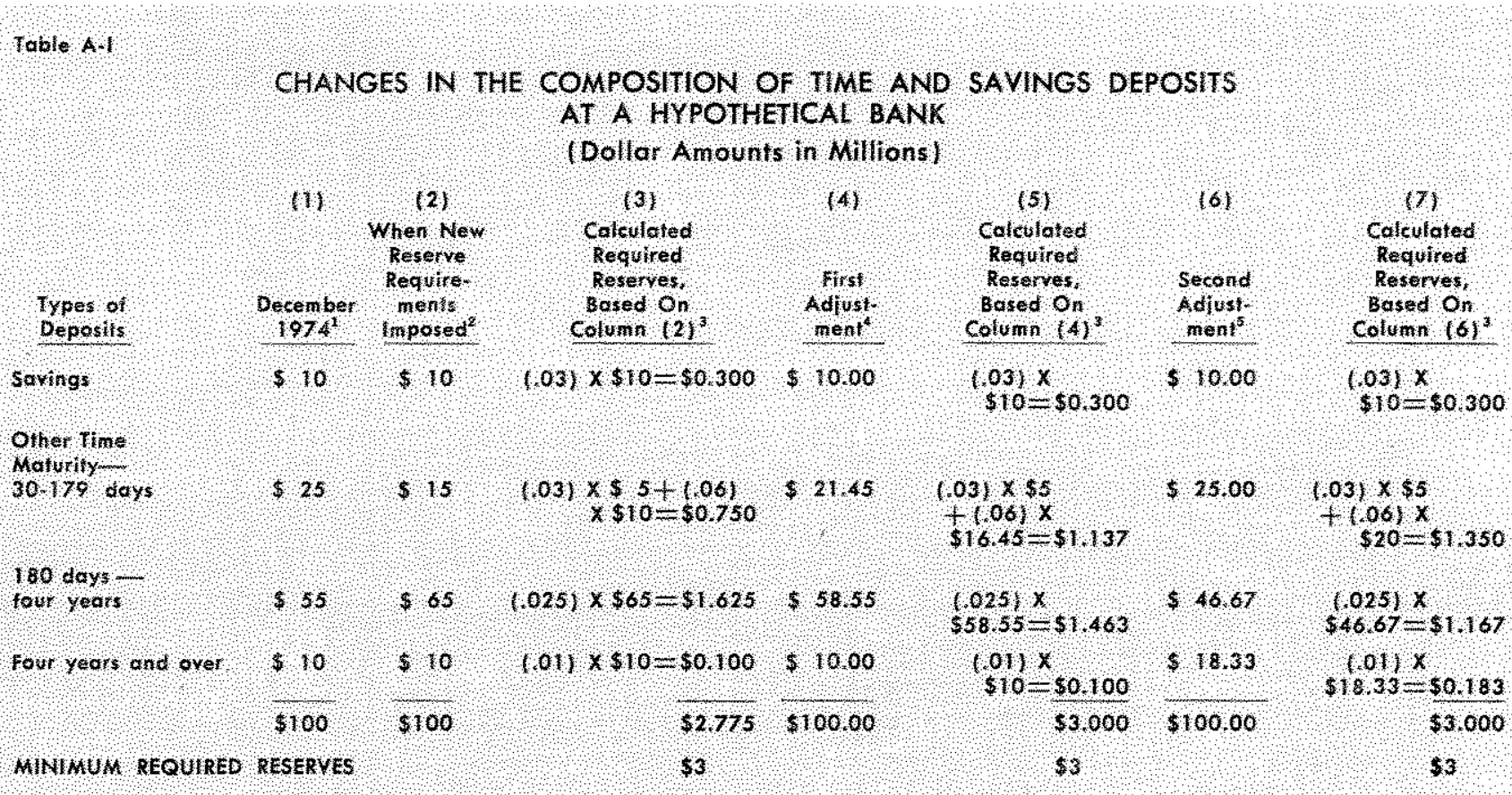

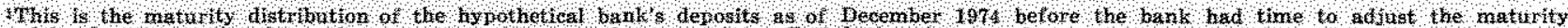

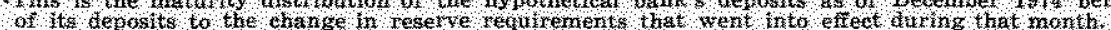

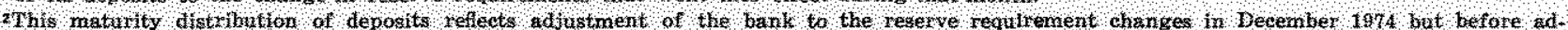

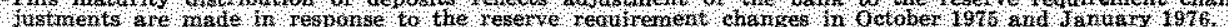

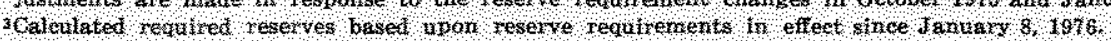

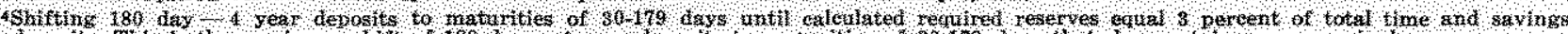

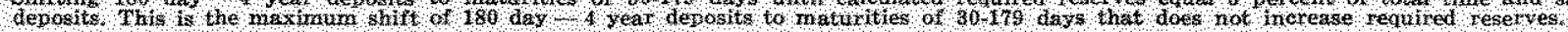

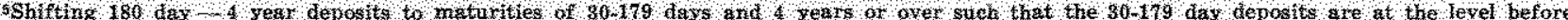

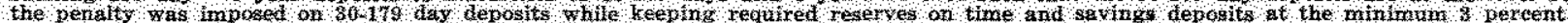

still be $\$ 3$ million. In this second possible adjustment the bank would increase its $30-179$ day deposits by $\$ 10$ million. This is more than the $\$ 8.33$ million increase in its deposits with maturities of 4 years and over. However, other cases can be constructed in which the combination of shifts in deposits to short and long maturities that keep required reserves unchanged involve greater shifts to long maturities than to short maturities. Therefore, the effect of the recent reserve requirement change on the average maturity of time deposits for the type of banks represented in Table A-I is uncertain.

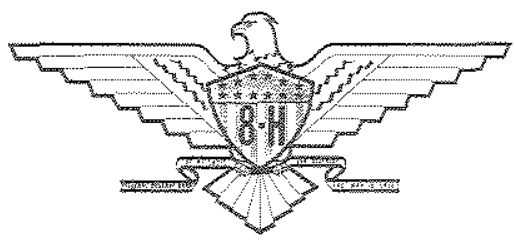

